\title{
Implementation of Zonation Policy in Sempadan River Tondano at Manado City
}

\author{
Goinpeace H. Tumbel* \\ Public Administration \\ Faculty of Social Science \\ Universitas Negeri Manado \\ Tondano, Indonesia \\ goinpeacetumbel@unima.ac.id
}

\author{
Jetty E. H. Mokat, \\ Public Administration, \\ Faculty of Social Science \\ Universitas Negeri Manado \\ Tondano, Indonesia \\ jettymokat@yahoo.co.id
}

\author{
Rico Mertosono \\ Public Administration \\ Faculty of Social Science \\ Universitas Negeri Manado \\ Tondano, Indonesia \\ ricomertosono@gmail.com
}

\begin{abstract}
This study aimed to describe, analyze and interpret the implementation of the zonation policy in the Tondano river border area, using qualitative research approaches and the type of research is case study research. The results of this study indicate that in the preparation of public spatial planning processes of the public consultation process was not implemented, the socialization and coordination between relevant agencies and community were not running as expected, there were buildings which not implemented provisions but had permits, weak capacity of resources both the resources of the government apparatus as implementor policy and budgeting support to control efforts, then the government has not been optimal in implementing policies, especially sanctions for those who commit violations by applicable regulations. The recommendation for the implementation of border zonation policy is the government needs to conduct a public consultation process before formulating the policy, the public should know about the plan to formulate zonation policy for the border area as well as being involved in the preparation of the policy, the government should consistently implement the policy, especially supervise and conduct legal processes for those who do not comply the policy and consistently do not permit any building which does not obey the policy.
\end{abstract}

Keywords: Policy Implementation, Zonation, River Border

\section{INTRODUCTION}

River border or riparian zone is an area of protection from aquatic ecosystems (rivers) and land, this area is filled with plants or trees, and construction is prohibited, because the river border, is intended to create and maintain the preservation and function of the river, and to protect the community from threats danger around rivers such as landslides and floods.

The socio-cultural conditions of the Indonesian people after the reformation Referring to the Law of the Republic of Indonesia Number 26 of 2007 concerning Spatial Planning, in article 3 the implementation of spatial planning is intended to present a productive, safe, comfortable national space and territory with the realization of harmony both in the natural and man-made environment, and the realization of environmental protection function in space and prevention of negative effects on the environment due to space utilization [1]. Then as a follow-up or as a derivative provision, the provisions are also regulated further related to spatial planning in the Tondano river border area in Manado City Regional Regulation No. 1 of 2014 concerning Spatial Planning for the Manado City Region in 2014-2034 in article 33, in item $b$, it is stated that the river area in Manado City which is categorized as a large river, and has been built yet a dike on the river bank, the width of the river border is 15 (fifteen) and already has a dike on the river bank, the width of the river border is 5 (five ) Meters, covering the Tondano River region and four other rivers [2].

Factually, the results of the study found there are many buildings function as dwellings stand in the border area, there are buildings that are built next to the river, and even there are buildings found just above the river. Successfully implementation of the policy will also be determined by how the policy itself is linear with the implementers of the policy (implementor) and also how the performance or the implementation of the policy. There are several elements influenced policy implementation such as policy standards, resources, information, communications, characteristics of implementing, agencies, political conditions [3]

The effectiveness of the policy will also be highly determined by several variables, such as the first aspect of communication, which is related to how the policy itself is communicated to the organization or the public; second, the aspect of resources, about the availability of supporting resources both human resources and facilities and facilities; third, the disposition aspect, regarding the willingness of the implementors conduct intended policy, and fourthly the bureaucratic structure relating to the suitability of bureaucratic organizations that are organizers or implementers of public policies [4].

\section{RESEARCH METHODS}

This research was conducted in the city of Manado in the region of the Tondano River Region, precisely in the three sub-districts traversed by the Tondano river, called the sub-districts of Wenang, Singkil and Paal Dua. This research also uses qualitative research methods. Sources of data are informants from the community who live along the Tondano river, the chief in the community within the Tondano river border, Manado City PUPR Office, research development of Manado City, Manado River 
Public Hall I Regional Office, Investment and Licensing Office Manado City, Manado Municipal PP Sat-Pol, which is Head of Operations and Control Section. Data collection techniques are done through observation, interview, and documentation. Data analysis techniques using an interactive analysis model [5].

\section{RESULTS AND DISCUSSION}

\section{Public Policy}

Public policy is an agreement or decision as a form of action to solve or overcome a public problem taken by the state through the state instrument, namely the government. Such as the Trias Politica concept, the government includes the executive, legislative and judiciary. Public problems have a broad impact and include consequences for people who are not directly involved. Public problems can be categorized into several categories. The first category, procedural problems, and substantive problems. Where procedural problems relate to how the government is organized and how the government carries out its tasks, while the substantive problem relates to the real effects of human activities, such as concerning freedom of speech, or environmental pollution. The second category based on the origin of the problem [6].

The term public policy has often been heard in daily life and in academic activities, such as in political science lectures, policy (policy term) may be widely used as in "Indonesian foreign policy", "Japanese economic policy" or Agricultural policy in developing countries or third world countries ". However, this term might also be used to refer to something more specific, for example, if we say government policies regarding debureaucratization and deregulation [7]. Another opinion stated public policy is whatever the government chooses to do and not do [8].

Furthermore, Anderson defines public policy as the behavior of some actors (educators, groups, government agencies) or a series of actors in a particular field of activity. The discussion on policy is inseparable from the interrelationship of interests between groups, both level of government and society in general [9].

\section{Public Policy Implementation}

It has been more than four decades since Pressman and Wildavsky in the 1970 s tried to do something to understand why the implementation of various programs designed by the federal government tends to fail when implemented by the state government, but on this day the phenomenon still repeated [10]. The phenomenon found in the field about the many failures in implementing various government development policies and programs, as reviewed by Presman and Wildavsky, is also no exception in developing countries [11]

The success of policy implementation is determined by five factors as follows: viability, theoretical integrity, scope, capacity, unintended consequences [12]. Meanwhile, Sabatier, said six main variables are seen as contributing to the success or failure of policy implementation. The six variables are: 1) Clear and consistent policy goals or objectives, 2) Strong theoretical support in formulating policies; 3) The implementation process has a clear legal basis that ensures the compliance of officers in the field and the target group; 4)
Commitment and expertise of policy implementers; 5) Stakeholder support; 6) Stability of social, economic, and political conditions [13].

\section{Models of Public Policy Implementation}

Referring to Ripley's opinion, policy implementation can be seen from two perspectives: implementation studies of two major factors: "compliance" and what's happening?" [14]. Following Ripley's opinion, the measure of the success of policy implementation can not only be seen in terms of the compliance of the implementers in following the SOP but also measured from their success in realizing policy objectives that manifest themselves in the form of policy impacts.

\section{Basic Zonation Policy of the River Border Area}

Republic of Indonesia Law Number 26 of 2007 concerning Spatial Planning and Regional Regulation of the City of Manado Number 1 of 2014 concerning Spatial Planning for the City of Manado in 2014-2034

Normatively, the implementation of Tondano River border zonation policy refers to the results of research data based on the provisions stipulated in Law Number 26 of 2007 concerning Spatial Planning, in this provision regulating spatial plan consists of, spatial planning, spatial use, and controlling the use of space.

\section{Spatial Planning}

The results of the research data showed the process of spatial planning community itself has never been involved. The public does not know how the process of formulating and managing spatial policy planning in Manado. Meanwhile, the community views this authority is the authority of the government. The Head of Spatial Planning Section at the Manado Public Works and Settlements Department (PUPR) stated the community was involved in the activities of the policy planning process through public consultation. However, the people living in the region of the Tondano river are not aware of it.

In fact, departing from research data, communication and coordination between agencies on the task of functions and authorities is less synergistic, especially between the implementation of tasks and authorities of both the PUPR Office and the Regional Research and Development Planning Agency (Bapelitbangda). Particularly in relation to the duties and authorities of drafting planning for spatial planning in Manado City, because between the two agencies is throw responsibility to each other.

In other words, in the spatial planning process as the implementation of the zoning policy for the Tondano river border area, the government has not yet opened up space for communities around the Tondano river area in the process of communication and public participation as in policy implementation activities and communication between organizations, social economic and political conditions and attitudes implementors' alignments with the policy implementation process have not been carried out properly, as stated by Van Meter and Van Horn.

It is the same as stated by Edwar III, who argues that the success or failure of a policy implementation is greatly 
influenced by communication factors or how the policy is socialized to the target group, then the readiness and availability of human resources as implementers, infrastructure and financial support, also the effectiveness and synergy between the bureaucratic organizational structures of policy implementers.

According to the constitution, it has been regulated every process of formulating laws and regulations, government regulations and even regional regulations on community involvement is a must, especially for the people who are directly related to the material to formulate the policy. It means every policy formulation should normatively involve public participation [15]. Other provisions are also clearly regulated in Article 1, paragraph 70, Manado Regional Regulation Number 1 of 2014, stated, "Community involvement in spatial planning is real participation of the community in the process of spatial planning, spatial use, and control of spatial use"[16]

\section{Space Utilization}

Policy implementers or the government from the data obtained shows there is no consistent attitude in terms of spatial use. Contrasting and even paradoxical where the government assists the community for renovating their buildings, meanwhile, is contrary or not according to the rules because the riverbanks cannot be erected. Manado City Regional Regulation Number 1 of 2014 in article 78 stated, related to the rules for zoning of rivers divided into, firstly stated that zoning for river borders is intended to maintain the authenticity and usefulness of the river itself, and is not permitted for activities that can cause effects to decrease river function, these effects include a reduction in river width, reduction in river depth and reduction in river capacity, the second is the utilization area used to maintain the function of springs around the river, and the third is, the control area is designated for river banks in anticipation or guarding overflowing river water, called a flood retention area.

In this policy it has been regulated, that river boundaries cannot be used for residential or business buildings, and it is prohibited to dispose of waste, but the current reality is that border areas are actually used as residential areas as well as business places, and the habits of people who dispose of waste into rivers are increasingly having a negative impact on the Tondano river itself, it is hoped that the spatial planning policy in the city of Manado will be able to overcome problems related to spatial planning in the Tondano river border area. This impartiality and inconsistency then encourages the community to relax or gives them the opportunity to build houses on the Tondano river border area.

So it is not surprising if found in the area there are or are filled with buildings, both houses for residents and business buildings. Some of these buildings even have land certificates and building construction permits. So the area becomes an area that is not in accordance with the designation. This occurs due to the inconsistency of the implementor's attitude (disposition) or a lack of partiality to the policy itself, resulting in weak supervision from the government. The success of policy implementation, especially in terms of utilization of the space, by Van Mater and Van Horn will run linearly with implementation and communication activities between organizations, characteristics of the implementor and the attitude of the implementer.

According to Purwanto and Sulistyatuti, under the development of governance, the current implementation agency is not only a monopoly of the government. Apart from the increasingly limited capacity of the government, in terms of budget, human resources, technology, and management capacity to be able to solve all public affairs by itself, the era of democratization also demands that the government be more open and more inclusive in providing space for civil society organizations and the private sector to be involved in implementation. a policy.

\section{Control of Spatial Use}

In Article 96, Paragraph 4, Manado City Regional Regulation Number 1 of 2014, stated "community involvement in controlling spatial use as referred in paragraph (1) letter $\mathrm{C}$ in the form of checking and maintaining in the use of space, which provides information or reporting of any spatial use activities at intended location. In this article it is very clear that the community should be the supervisor of the wrong use of space, but they are the ones who commit violations, because they say that they also need a place to live while the development process carried out by the government is taking too long, and also the village government does not. once forbade people to keep building and renovating their homes.

In controlling development, the government uses a permit document that guarantees that the building is in accordance with the provisions of space utilization, but in reality it shows differences in the field because there are many buildings that violate spatial planning, but they have building permits. This is not in line with and violates Article 37, Paragraph 7 of Law Number 26 Year 2007 concerning Spatial Planning, it is said that "all office holders in the government who are authorized to issue permits for spatial use are not permitted to grant permits that violate spatial planning regulations". Related parties, namely DPM-PTSP said that the mistake in issuing the permit above 2014 was the fault of the community, because they argued that the permit that had been issued was equipped with a limit to build a building, but in reality in construction, the building owner was building beyond has been determined because they think that the land is his.

Regarding control carried out by the government, it has never given sanctions to people who violate spatial planning. The village government does not even know that there are sanctions for people who violate them because they do not know the rules. This is not in line with Article 92, Paragraph 1 and 2, Regional Regulation of the City of Manado Number 1 of 2014 that "All parties found to have violated these regulations can be given both criminal and administrative sanctions. Sanctions against violators as regulated in paragraph 1 , namely in the form of a warning in the form of a written letter; termination of activity within a certain period of time; dismissal from obtaining service facilities; construction sites to be closed; the license issued will be revoked; the permit will be canceled; existing buildings will be put in order; will be revitalized to the environment; and / or sanctions in the form of fines ", but the government says that the process 
cannot be carried out entirely like that, because they also have to prioritize the principle of justice.

Public policy is the goal form of actions put forward by everyone in an organization, or government in a country, which presents opportunities expressed in overcoming existing problems to meet a predetermined goal and to achieve certain goals, Carl J. Friedrich in Agustino [16]. A policy in its implementation also requires a process of supervision or monitoring with an assessment to implement control to comply with a predetermined plan, policy control can cover three dimensions, as follows: 1) Policy monitoring, or policy oversight; 2) Policy evaluation; 3) Rewarding policies. Supervision is often understood as "ongoing evaluation" or "formative evaluation" [17]

Referring to various findings and previous studies, the implementation of spatial planning policies related to the zoning of the Tondano river border area in Manado City shows that the spatial planning dimensions, which include aspects: spatial planning, spatial use and spatial use control, have not yet achieved their objectives. The policy has not been implemented due to several factors that support the implementation of the implementation performance has not been implemented or empowered. These factors, among others, are related to communication or socialization of policies that have not been carried out properly, even the dimensions of implementation activities and communication between organizations or implementing agencies have not been carried out properly. This resulted in not building public participation in the process of formulating and implementing policies, inadequate resource aspects, relatively insufficient alignments of implementers, and elements of supporting the network of bureaucratic organizational structures that were running well. Then the factors of socio-economic and political environmental conditions, both internal implementors and target groups, are relatively less conducive, the characteristics of the implementing agents are relatively less supportive for the realization of the performance of public policy itself.

There is also a factor of weak resources, both human resources and other supporting resources such as: facilities, financial support and so on. Likewise, the government has not been consistent in implementing this policy as a form of effort to overcome development on the Tondano riverbank, there is no effort from the village government to prevent and prohibit development on the Tondano river border, the government also admits that the current spatial policy has not been effective in regulating spatial planning in the city of Manado, buildings on the border of the Tondano river which clearly violate the rules but still issue certificates and building permits, the government is difficult to overcome development because the city of Manado does not have a basic spatial plan, the government has also not been able to provide appropriate sanctions with spatial planning policies for violating communities, there has not been any visible impact from the development process apart from aesthetic point of view, and the existing development has not been able to reduce the negative impacts resulting from unregulated use of space.

The government as the spatial policy implementor in the city of Manado needs to evaluate and formulate a policy formulation aimed to solve problems in the area of the river border building communication through proper public consultation with the target group and related elements, building commitment and joined for a common goal.

\section{CONCLUSION}

Based on the results and discussion, it can be concluded the implementation of the zonation policy of the Tondano river border area in Manado has not been done well. This appears in the dimension: Spatial Planning which shows the process of community spatial planning itself has not been involved. Then, spatial Use, Policy Implementers or government parties have not had a consistent attitude in terms of spatial use. Contrasting and even paradoxical where the government assists the community for renovating their buildings. Meanwhile, it is contrary or not according to the rules because the riverbanks cannot be erected. And the Control of Spatial Use, the government (the implementor agent) has not properly controlled through supervision over the implementation of the zonation policy on the Tondano river border area stands the building and residential buildings which some have building permits (IMB).

\section{ACKNOWLEDGMENT}

These specials gratitude presented to:

1. The Government Manado City, in this case, the National Unity and Political Agency of Manado, which has given and issued a permit to research Manado.

2. Manado Public Works and Spatial Planning Office, Manado Regional Research and Development Planning Agency, Manado Integrated Investment and Licensing Agency, Regional Hall of Sulawesi River I.

\section{REFERENCES}

[1] R. Indonesia, Undang-Undang Nomor 26 Tahun 2007 tentang Penataan Ruang. 2007.

[2] Manado, "Peraturan Daerah Kota Manado Nomor 1 Tahun 2014 tentang Rencana Tata Ruang Wilayah Kota Manado Tahun 2014-2034;" Manado, Indonesia, 2014.

[3] D. Van Meter and C. Van Horn, The Policy Implementation Process: A Conceptual Framework", in Administration and Society. London: Sage, 1975.

[4] Edward III and George C., Implementation Public Policy. Washington: CongressionalQuarterly, Inc., 1980.

[5] M. B. Miles and M. A. Huberman, Analisis Data Kualitatif: Buku Sumber Tentang Metode-Metode Baru. 2012.

[6] T. J. Lowi, "American business, public policy, case-studies, and political theory," in Paradigms of Political Power, 2017.

[7] B. Winarno, "Kebijakan Publik (Teori, Proses, dan Studi Kasus)," Caps. 2012. 
[8] T. R. Dye, Understanding Public Policy., Prentice-H. Englewood Cliff, N.J, 1975.

[9] J. E. Anderson, Public policymaking: Second Edition. 1979.

[10] J. L. Pressman and Wildavsky, Implementatiion. Barkley and Los Angels: University of California Press, 1973.

[11] Purwanto, A. Erwan, Sulistyastuti, and R. Diah, Implementasi Kebijakan Publik, Konsep dan Aplikasinya di Indonesia. Yogyakarta: Gava Media, 2012.

[12] A. L. Schneider, "Studying policy implementation: A Conceptual Framework," Eval. Rev., 1982.

[13] E. A. Sabatier, "Top-down and bottom-up approaches to implementation research.," $J$. Public Policy, vol. Vol. 6, 2000.

[14] B. Ripley, Randall, Policy Analysis in Political Science. Chicago: Nelson-Hall, 1985.

[15] R. Indonesia, "Undang-Undang Nomor 12 Tahun 2011 tentang Pembentukan Peraturan PerundangUndangan.” Pemerintah Republik Indonesia, 2011.

[16] L. Agustino, Dasar- dasar Kebijakan Publik. Bandung: Alfabeta, 2008.

[17] R. Nugroho, Public Policy: Dinamika Kebijakan, Analisis Kebijakan, dan Manajemen Politik Kebijakan Publik. 2017. 